\title{
フォスファターゼに及ぼす三, 三抗生物質の影畓
}

和歌川醫大內科(指導 岩鶴龍三教授) 器 野 義 美

Influences of some Antibiotics on the Phosphatase.

Yoshimi Miyano

\section{第 1 章 緒 言}

余去さきに二，三內科的疾患の血清並に㽷のつ ルカリ及び酸フォの態度について報告する所が。 つた，然るにフォの作用は程々の化學物啠の共存 により賦活又は抑制されることが以前から知られ ている.その主なるるのは第1裁にに示される樣に， 多く無機イォンであつて，份機物の影響はあまり 硼究されていない，因に南條”はメチール線、メチ ーレン青,ピロール殬,ブリラントクレシール青及 びトリパフラビン等の集機出素が，藏驗管內試驗

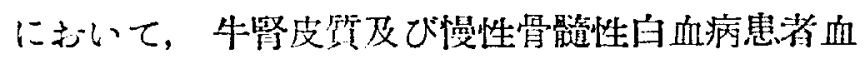

液アルカリフォ力價意强度に減弱せしむることを

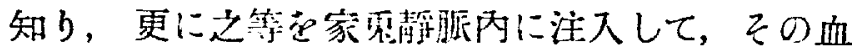

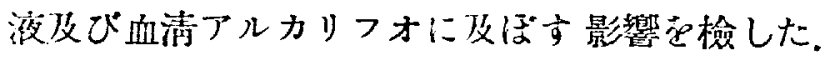
更に堀井 ${ }^{3}$ はアルコール，プトン，フォルマリン の酸及びアルカリフォ汇教する影響を檢して，い

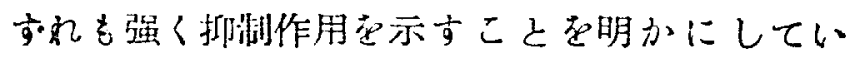

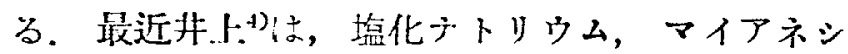
ン, 塩化 d-tubocurarine, 硝酸ストリキニン, 荻

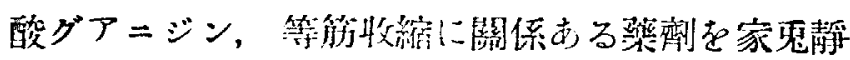
脈內に用いて，方り血清アルカリ並に酸フオに及

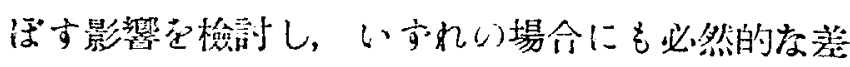

第1表フォに及にす化學物筫の影翌

\begin{tabular}{|c|c|c|c|}
\hline 物 賢 名 & 賦活メは抑制 & 苦 & 献 \\
\hline $\begin{array}{l}\mathrm{K} \cdot, \mathrm{Sr}^{*}, \mathrm{Ba} *, \\
\mathrm{Li}, \mathrm{Be}^{*}\end{array}$ & 輕度抑制 & 琴フオ & Jenner, Kay: J. Biol. Chem., 93: 733, 1931 \\
\hline $\mathrm{Zn} \cdots$ & 輕度押制 & & 同 i \\
\hline $2 \mathrm{n}^{\circ}$ & 賦活 & $\begin{array}{l}\text { 細菌フォ } \\
\text { 腎フォ }\end{array}$ & $\begin{array}{l}\text { Bett, Wynne: Biochem. J. 32: 563, } 1938 \\
\text { Jenner, Kay: J. Blol. Chem., 93: 733, } 1931\end{array}$ \\
\hline $\mathrm{Ca}{ }^{*}$ & & 假骨フォ & 桑原: j. Biochem., 16: 403, 1932 \\
\hline $\begin{array}{l}\mathrm{Ag}, \mathrm{Pb}^{*}, \mathrm{Cu}^{*} \\
\mathrm{Hg} \cdot *, \mathrm{Al}^{\cdots}, \mathrm{Ni}^{\circ}\end{array}$ & 强〈抑制 & & Jenner, Kay: J. Biol. Chem., 93: 733, 1931 \\
\hline $\mathrm{Mn} \cdots$ & 賦 & 例外与お万 & 堀井等：Arb III. Abt. aust. Inst. Kyoto, C, No. 37,1932 \\
\hline $\begin{array}{l}\mathrm{Cl}, \mathrm{Br}^{*} \cdot \mathrm{J}^{*}, \mathrm{JO}_{3}{ }^{\circ} \\
\mathrm{Co}_{3}{ }^{\circ}, \mathrm{So}_{3} \cdot \cdot, \mathrm{SO}_{4}^{*} \cdot\end{array}$ & 影翌なし & & Jenner, Kay: J. Biol. Chem. 93: 733, 1931 \\
\hline $\mathrm{No}_{3}: \mathrm{NO}_{3}, \mathrm{No}$ & 時に輕度賦活 & & 同 \\
\hline $\mathrm{F} \cdot, \mathrm{Bo}_{3} \cdots, \mathrm{M}_{0} \mathrm{O}_{4} \cdots$ & & & \\
\hline $\mathrm{CN}^{-}$ & & & Albers: B., $68: 1443,1935$ \\
\hline 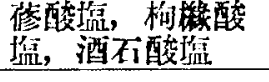 & 制 & \multirow{3}{*}{ 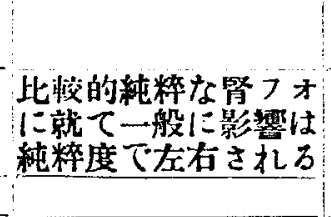 } & Jenner, Kay: J. Biol. Chem. 93: 733, 1931 \\
\hline $\begin{array}{l}\mathrm{HS} \text { 化合物 }(子 天 \\
\text { テ1ン, }\end{array}$ & 抑 & & Albers: B., $68: 1443,1935$ \\
\hline$\alpha \cdot \boldsymbol{P} ミ$ 酸 & 賦 & & O.Bodansky: J.Biof. Chem., 114:273, 1936. 115: 101, 1936 \\
\hline \multirow[t]{2}{*}{ アスコルビン酸 } & & 植物つオ & $\begin{array}{l}\text { Giri: H., 245: } 185,1937 . \\
\text { Pyle, Fisher, Chark: J. Biol. Chem., 119: 283, } 1937 .\end{array}$ \\
\hline & \multirow{4}{*}{$\begin{array}{l}\text { 抑 制 } \\
\text { 賦 活 }\end{array}$} & 腸管フォ & Euler: Ark. Kem. Miueral. Geol., 11B, Nr.42, 1936 \\
\hline 胆汁酸 & & & Uraki; J. Biochem., 14: 123, 1931 \\
\hline 碓酸揾，亞碓酸 & & \multirow{2}{*}{$\begin{array}{l}\text { 解糖作用之共に } \\
\text { 見己れる(細囷) }\end{array}$} & Pett, Wynne: Biochem. J., 32: 563, 1938 \\
\hline 濫 & & & Pett, Wynne: Biochem. J., 28: 365, 1934 \\
\hline
\end{tabular}


琾を認め得なかつたと郝している。

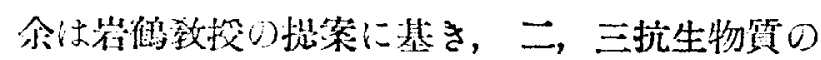
フオに收ばす影響老倵驗管內において貫驗し，與

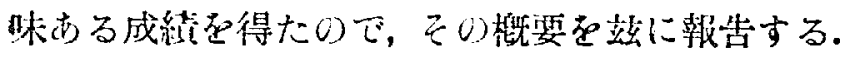
蓋し感氿症に樭する抗生物留の使用は現今治療界 の王座を占めるものであり，それ等がフォ皮活 す影響を檢討しておくことは無意味ではなかるう と考えられるからである。

\section{芽 2 章 菑驗方法}

アルカリフォ源として成年健康人血清を，酸フ

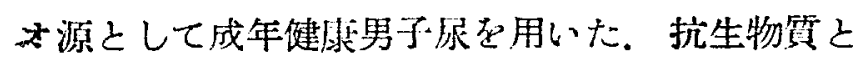
しては今日一般に用いられる门股のペニシリンカ リウム(武时)(以下 $\mathrm{PK}$ と略す), ジハイドロスト レプトマイシン(三共) (SM)，テラマイシン (Le derle)(AM), クロラムフェニコール(Park Davis)

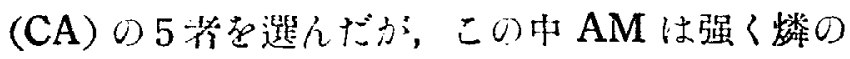
反應を是し，フォ力價の测定を因難在らしめるの で，之を除外せざる得なかつた。

なお實驗方法の細部は第 2 表に示す通りで對 照, 第 I 试驗, 第 II 试驗滆 3 㑑のコルベンを探り, 表の近り操作した。かくして得たるPの梿上り， 同樣操作在行つた上孵卵器內に保存することなく

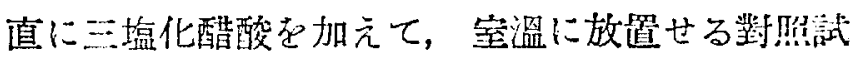

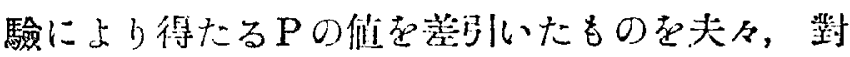
品优，第 I 試驗值，第 II 試驗值とした。

\section{第 2 表 實驗方法}

\begin{tabular}{|c|c|c|c|}
\hline 操作 & 對 昭 & I & II \\
\hline 基筫溶液 & $5.0 \mathrm{cc}$ & $5.0 \mathrm{cc}$ & $5.0 \mathrm{cc}$ \\
\hline 緩銜波 & $5.0 \mathrm{cc}$ & $5.0 \mathrm{cc}$ & $5.0 \mathrm{cc}$ \\
\hline 血清入は辰 & $1.0 \mathrm{cc}$ & $1.0 \mathrm{cc}$ & $1.0 \mathrm{cc}$ \\
\hline 抗生物質 & 源加さす & $50 \mathrm{mg}$ & $10 \mathrm{mg}$ \\
\hline \multicolumn{4}{|c|}{$38.0^{\circ} \mathrm{C} \quad 48$ 時間 } \\
\hline 25\%三塩化醋酸 & $2.0 \mathrm{cc}$ & $2.0 \mathrm{cc}$ & $2.0 \mathrm{cc}$ \\
\hline
\end{tabular}

立に抗生物筫の添加量を50mg, 及び $10 \mathrm{mg}$ と決 定したのは，分子量の判明せるPK, SM, TM, CA につき大約 $1 / 100 \mathrm{M}, 1 / 500 \mathrm{M}$ 程度の試驗管內漂度を 得たい笉であつて他に特別の意味を有しない，叉 PK，SMは完全に溶解せしめ得たか，TM，CMに
於ては所定 $0 \mathrm{pH}$ 並に $38^{\circ} \mathrm{C}$ 江於て完全な溶解 は見られす一部コルベン底に沈澱として殘存し

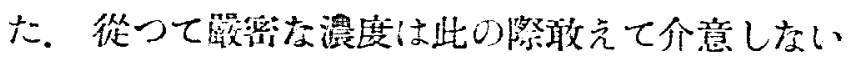
ことつした.

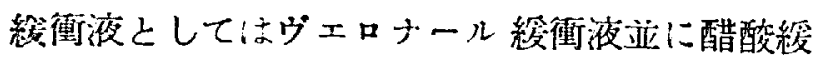
衙渡を夫々 $\mathrm{pH} 9.0$ 及び $\mathrm{pH} 4.4$ に調製して使用 した. 又抗生物質源加の前後において pH の變動

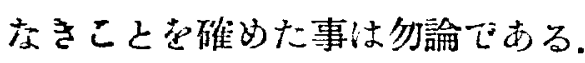

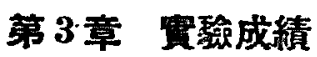

第 1 節 ペニシリン

1929年 Flemmingにより發見せられ，Penicillium notatum 其他の Penicillia 及び Aspergill $\mathbf{i}_{\mathbf{i}}$ より抽出慜造せられる。その棈造:5は<smiles>[R]C(=O)NC1C(=O)N2CC(C(C)(C)C)SC12</smiles>

と想定せられ $\mathrm{F}, \mathrm{G}, \mathrm{X}, \mathrm{K} の 4$ 盉火々 $\mathrm{R}$ として

$$
\begin{aligned}
& \mathrm{CH}_{3} \cdot \mathrm{CH}_{2} \cdot \mathrm{CH}=\mathrm{CH} \cdot \mathrm{CH}_{2}- \\
& \mathrm{C}_{6} \mathrm{H}_{5} \cdot \mathrm{CH}_{2}- \\
& \mathrm{OH} \cdot \mathrm{C}_{6} \mathrm{H}_{4} \cdot \mathrm{CH}_{2}- \\
& \mathrm{CH}_{3} \cdot \mathrm{CH}_{2} \cdot \mathrm{CH}_{2} \cdot \mathrm{CH}_{2} \cdot \mathrm{CH}_{2} \cdot \mathrm{CH}_{2} \cdot \mathrm{CH}_{2}-
\end{aligned}
$$

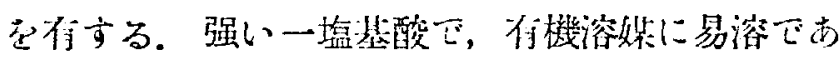
るか水には難溶である．然るにこのアルカリ金虽 との塩は容易に皮に溶放る。グラム陽性菌, Neisseria, Treponema 及び或種わ Hemophilusに對 し $0.001 \sim 1.0 \mathrm{r} / \mathrm{ml}$ で仿效とされている.この血 中倠效濃度は $20,000 \sim 100,000$ 單位の非經口的投 與により獲得される。

余は武时裂結晶ペニシリンカリウムを用いて上

\begin{tabular}{|c|c|c|c|c|}
\hline 番 & 號 & 對 䐎 & $I$ & II \\
\hline \multicolumn{3}{|r|}{0.046} & 0.044 & 0.042 \\
\hline & 2 & 0.025 & 0.027 & 0.026 \\
\hline & 3 & 0.037 & 0.038 & 0.035 \\
\hline
\end{tabular}
述の方法に從い實驗した。 その成續を表示する己 第 3〜4 表の樣になる。

第3 表 血清アルカリフオに對するPKの作用 
第4 关 尿酸フォ!對するPK の作用

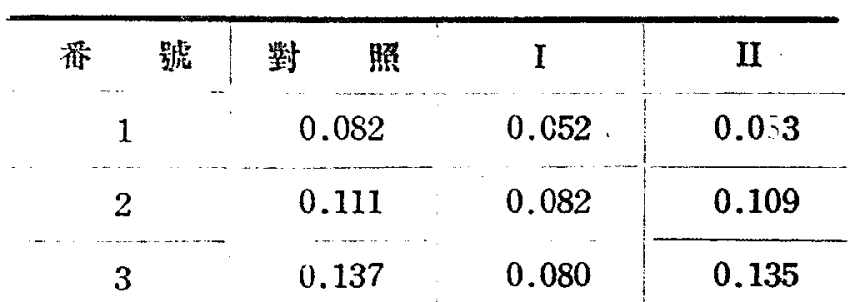

郎古 PK は血㴮アルカリフォに對しては何等の 影響をる及ばさないか，局の酸フオに對しては高

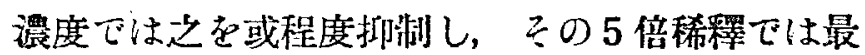
早殆んど影響を示さない。

第2節 ストレプトマイシン

1944年 Schatz, Bugie 及び Waksmann によ b Streptomyces griseusより取出され，方の分 子式は， $\mathrm{C}_{21} \mathrm{H}_{37}{ }_{39} \mathrm{~N}_{7} \mathrm{O}_{12}$ と悡定されている゙5. 强い アルカリ性で水に易溶, 低級アルコールに難溶, 他の付機溶桇には溶解しない，0.1〜2.0r/ml でグ ラム陽性及び陰性菌，殊に結核菌に准效である。 $0.5 \mathrm{~g}$ の注射で $2 \sim 3$ 時間血中任效濃度を保持す る.

余はジハイドロストレブトマイシン(三共) 存用 いて㙰驗在行い，次の成續を得た。

第 5 表 血清アルカリフォ!こ對する SM 作用

\begin{tabular}{|c|c|c|c|c|c|}
\hline 潘 & 諕 & 對 & 照 & I & II \\
\hline & & \multicolumn{2}{|c|}{0.048} & 0.032 & 0.051 \\
\hline & & \multicolumn{2}{|c|}{0.040} & 0.023 & 0.039 \\
\hline & & & & 0.029 & 0.048 \\
\hline
\end{tabular}

第 6 表 尿酸フォに對する SM 作用

\begin{tabular}{|c|c|c|c|}
\hline 番 號 & 對 照 & I & II \\
\hline 1 & 0.170 & 0.168 & 0.170 \\
\hline 2 & 0.160 & 0.157 & 0.165 \\
\hline 3 & 0.099 & 0.098 & 0.099 \\
\hline
\end{tabular}

師ち SM は高い濃度でアルカリフォを抑制し， その5 倍稀釋では殆んど影響せす，酸フオに對し ては高濃度，低濃度共に何等の作用をる及ぼさな w.
第3 節 テラマイシン

Finlay 等により 1950年, Streptomyces vimosus

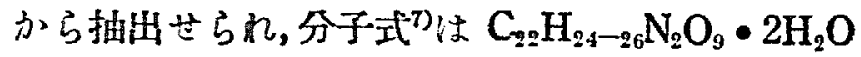
上想定されている $1 \sim 3 \sim 5 \mathrm{r} / \mathrm{ml}$ で各䅣の細菌に 對し有效て， $1 \mathrm{~g}$ 宛 6 時間酉投與に上り血中有效 量を持数することが出柬る上言う。

䞨には标貶の Pfizer 製品芭用いて行つた䐝驗成 綘を示す。

第7表 血清アルカリフォに對するTMの作用

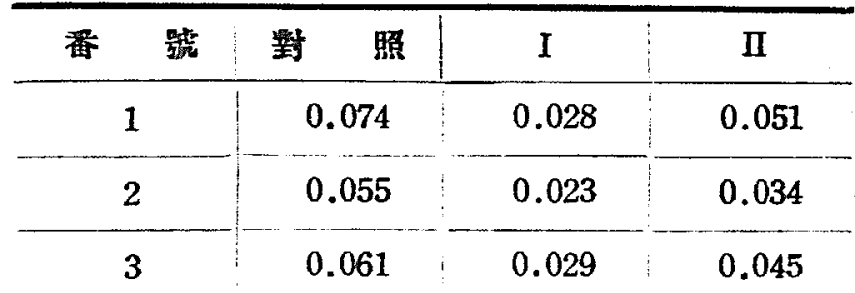

第 8 表 尿酸つォに對する TMつ作用

\begin{tabular}{|c|c|c|c|}
\hline 番 號 & 曋 照 & I & II \\
\hline 1 & 0.134 & 0.051 & 0.058 \\
\hline 2 & 0.084 & 0.020 & 0.024 \\
\hline 3 & 0.159 & 0.044 & 0.067 \\
\hline
\end{tabular}

第 7 ～表に示す通り TMは血清のアルカリフ オ並に尿の酸フオに㖶し可なり强く抑制作用を現 かしている。

第 4 節 クロラムフェニコール

1947年，Ehrlich 等により，叉1948年 Gottlieb 等により各獨立に Streptomyces venezuelae に より得られ，次の樣应構造8)の確定と共に近時は 合成を可能となつた。<smiles>O=C(NC(CO)C(O)C(Cl)Cl)C(O)c1ccc([N+](=O)[O-])cc1</smiles>

$0.5 \sim 5.0 \mathrm{r} / \mathrm{ml}$ で殊に腸チフス菌に有效じ， 0.2 $\sim 0.3 \mathrm{~g}$ の 2 4 時間底經口投與によ 々 $20 \sim 80 \mathrm{r} / \mathrm{ml}$ の血中濃度か得られる之言う。

余は Park Davis 社製品を用いて實驗し次の成 樍を得た。 
第9表 血潆アルカリフォに對するCAの作用

\begin{tabular}{|c|c|c|c|c|}
\hline 番 & 號 & 對 照 & $I$ & II \\
\hline & & 0.048 & 0.052 & 0.051 \\
\hline & & 0.026 & 0.026 & 0.025 \\
\hline & & 0.031 & 0.032 & 0.032 \\
\hline
\end{tabular}

第10表 尿酸フォに對すっ CA つ作用

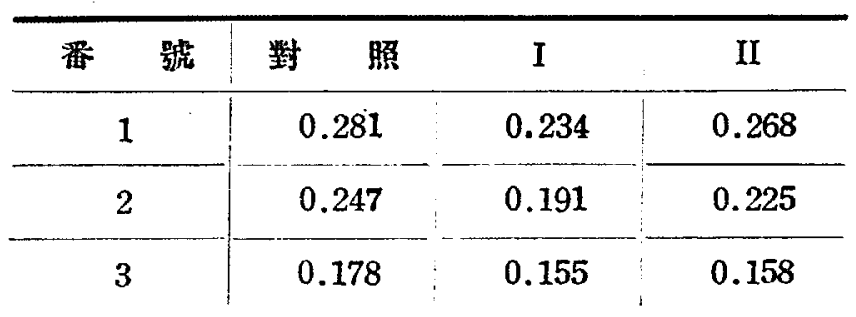

即与 CA は血清のアルカリフォに對しては格別 の影響を示さないか，屎の酸つオに對しては之を 抑制するものと見られる。

\section{苐 4 章 總 括}

血清のアルカリフォ及び尿の酸フォに對する
PK, SM, TM, CA の影響を試驗管內で實驗して 次の成績定得た。

1. PK :血清アルカリフォに對しては何等の 影䇾をる及ぼさないか，尿の酸フオを抑沜する。

2. SMは反對に血清のアルカリフォを抑制し。 尿の酸フォには影響を與えない。

3. TMは血清アルカリフォ並に尿の酸フォに 齗し虽く之抑制する。

4. CAは血清アルカリフォには影響せす尿の 酸フオを抑相する。

（本論文の要旨は昭和 27 年 4 月第 38 回日本消化機病學 會總會で登表しだ)。

\section{文献}

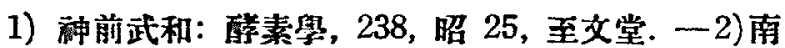

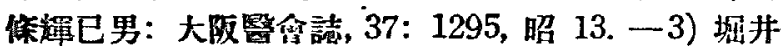
與喜：大阪堅会誌，43: 810, 昭 19. -4) 井上棓一： 日菜苓詓, 48: 16, 昭 27. -5) A.L. Baron: Hand book of Antibiotics: 184, 1950. Reinhold Publishing Corporation. -6) A. L. Baron: p. 222. -7) A.L. Baron: p. 242. - \&) A.L.Baron: p. 85. 